\title{
Demographic and clinical profile and functional outcomes of patients with spinal cord injury after rehabilitation
}

\author{
Omurilik hasarlı hastaların demografik ve klinik özellikleri ve \\ rehabilitasyon sonrası fonksiyonel sonuçları \\ Seçilay Güneş, Yeşim Kurtaiş Aytür, Haydar Gök, Şehim Kutlay, Neşe Güneş, Birkan Sonel Tur, Ayşe A. Küçükdeveci \\ Department of Physical Medicine and Rehabilitation, Medical Faculty of Ankara University, Ankara, Turkey \\ Received / Geliş tarihi: September 2016 Accepted / Kabul tarihi: October 2016
}

\begin{abstract}
Objectives: This study aims to analyze the demographic and clinical properties of patients with spinal cord injury (SCI) and to investigate the functional outcomes after rehabilitation.

Patients and methods: In this retrospective and descriptive study, we investigated a total of 118 SCI patients (74 males, 44 females; mean age $41 \pm 16$ years; range 13 to 74 years) with full records who were admitted to our rehabilitation program between January 2005 and December 2010 . Demographic characteristics of the patients, etiological factors, time since injury, length of hospital stay, level of injury, as assessed by the American Spinal Injury Association (ASIA) Impairment Scale and functional status, as assessed by the Functional Independence Measure (FIM ${ }^{\mathrm{TM}}$ ) on admission and discharge were analyzed. Complications related to SCI were also noted. Characteristic features of the patients', frequency of complications, and functional and neurological recovery were evaluated.

Results: Of the patients, 70\% were tetraplegic. The median time since injury was four months (IQR: 1 to 15 months), while the median length of stay was 76 days (IQR: 46 to 104 days). Four of 47 patients (8\%) with Grade A (complete) according to the ASIA Impairment Scale on admission progressed to Grade B on discharge. Functional independence measure motor scores showed significant improvements at discharge $(\mathrm{p}<0.0001)$. The most common complications were urinary tract infections (70\%), pressure ulcers (31\%), and pain (28\%).

Conclusion: Inpatient rehabilitation in a tertiary referral hospital appears to provide substantial functional and motor gains in patients with SCI. Based on our study results, considerable improvement in the activities of daily living, as assessed by FIM motor scores, can be achieved with rehabilitation.
\end{abstract}

Keywords: Function; outcome; rehabilitation; spinal cord injury.

$\ddot{O Z Z}$

Amaç: Bu çalışmada omurilik yaralanmalı (OY) hastaların demografik ve klinik özellikleri incelendi ve rehabilitasyon sonrasında fonksiyonel sonuçlar araştırıldı.

Hastalar ve yöntemler: Bu retrospektif ve tanımlayıcı çalışmada Ocak 2005 - Aralık 2010 tarihleri arasında kliniğimizde rehabilitasyon programına alınmış, kayıtları eksiksiz olan toplam 118 OY'li hasta (74 erkek, 44 kadın; ort. yaş $41 \pm 16$ yıl; dağılım 13-74 yıl) incelendi. Hastaların demografik özellikleri, etyolojik faktörler, yaralanma sonrası geçen süre, hastanede yatış süresi, Amerikan Omurilik Derneği (ASIA) Bozukluk Ölçeği ile değerlendirilen yaralanma seviyesi ve İşlevsel Bağımsızlık Ölçütü (FIM ${ }^{\mathrm{TM}}$ ) ile değerlendirilen fonksiyonel statü hastaneye yatış ve taburculuk sırasında analiz edildi. Omurilik yaralanmasına bağlı komplikasyonlar kaydedildi. Hastaların karakteristik özellikleri, komplikasyonların görülme sıklığı ve fonksiyonel ve nörolojik iyileşme düzeyleri değerlendirildi.

Bulgular: Hastaların \%70'i tetraplejik idi. Yaralanma sonrası geçen medyan süre dört ay (IQR: 1-15 ay) iken, medyan hastanede yatış süresi 76 gün (IQR: 46-104) idi. ASIA Bozukluk Ölçeğine göre yatışta Evre A (komplet) olan 47 hastadan dördü (\%8) Evre B’ye ilerledi. İşlevsel Bağımsızlık Ölçütü motor skorları taburculukta anlamlı iyileşme gösterdi $(\mathrm{p}<0.001)$. En yaygın görülen komplikasyonlar idrar yolu enfeksiyonları $(\% 70)$, bası yarası (\%31) ve ağrıdı $(\% 28)$.

Sonuç: Üçüncü basamak bir hastanede yatarak rehabilitasyon OY’li hastalarda önemli fonksiyonel ve motor kazanımlar sağlamaktadır. Çalışma sonuçlarımıza göre, FIM motor skorları ile değerlendirilen günlük yaşam aktivitelerinde rehabilitasyon sonrasında önemli düzeyde iyileşme elde edilebilir.

Anahtar sözcükler: Fonksiyon; sonuç; rehabilitasyon; omurilik yaralanması.

Corresponding author / İletişim adresi: Seçilay Güneş, MD. Kars Devlet Hastanesi Fiziksel Tıp ve Rehabilitasyon Kliniği, 36200 Kars, Turkey. e-mail / e-posta: yalices@hotmail.com 
The incidence of spinal cord injury (SCI) is reported to be between 10.4 and 83 cases per million per year. ${ }^{[1]}$ The functional, economical, physiological and social impairments are devastating for each individual. The SCI patients may face many complications during their lifetimes and they need inpatient rehabilitation at certain times. The aim of rehabilitation in patients with SCI is to reach optimal independence, provide a satisfactory quality of life, and to treat secondary complications related to SCI. Rehabilitation programs are long, exhausting and costly processes for the patient and families, but it is important to improve functional recovery. Not only acute spinal cord injured individuals benefit from rehabilitation programs, but also chronic SCI patients show improvements in their functional status as well.

Since rehabilitation facilities are not sufficient in Turkey, it is crucial to have a detailed understanding of the epidemiological data in order to plan services for both nationwide and on an individual basis for each rehabilitation center. Yet, there is no registry for the collection of data related to SCI patients. So, it is important to collect all available data to get an idea about the characteristics and outcomes of patients with SCI.

This retrospective and descriptive study aimed to analyze the demographic and clinical properties of patients with SCI and to investigate the functional outcomes after rehabilitation.

\section{PATIENTS AND METHODS}

Patients admitted to the Department of Physical Medicine and Rehabilitation, Medical Faculty of Ankara University Hospital between January 2005 and December 2010 were reviewed retrospectively. The data on first admissions to our hospital were included in the study. A total of 118 SCI patients (74 males, 44 females; mean age $41 \pm 16$ years; range 13 to 74 years) with full records were included the study. The only criterion for admission to the rehabilitation unit was medical stability to participate actively in a rehabilitation program. Demographics, etiological factors, time since injury, length of stay in the hospital during rehabilitation period, level of injury (The American Spinal Injury Association [ASIA], ASIA Impairment Scale [AIS]) and functional status (Functional Independence Measure; FIM $^{\mathrm{TM}}$ ) at admission and discharge were recorded. Complications occurring in association with SCI during inpatient rehabilitation and other relevant information was also noted.
Since standardized physical examination is the best way to evaluate spinal cord injured patients, ASIA AIS was used to assess motor and sensory levels of injury. The AIS grade A indicates complete spinal cord injury, and AIS grades B, C and D indicate incomplete SCI. ${ }^{[2]}$

The FIM is a widely used outcome measure for assessing physical and cognitive disability. ${ }^{[3]}$ It consists of 13 motor and five cognitive items with an established validity, reliability, and a sensitivity to change. ${ }^{[4]}$ Motor FIM includes feeding, grooming, dressing, toileting and mobility items. Cognitive FIM assesses communication, social interaction, problem-solving and memory. Possible scores range from 18 to 126 with lower scores indicating more dependence. The validated Turkish version of FIM was used in this study. ${ }^{[5]}$

All patients received an interdisciplinary rehabilitation program led by a physical and rehabilitation medicine physician. Different components of FIM were scored by relevant members of the team within 72 hours of admission and before discharge. All patients had a comprehensive rehabilitation program, including medical and nursing care, physical and occupational therapy. The aim of the rehabilitation program was to optimize functional independence as well as to educate the patient and the caregivers regarding the medical care and prevention of the complications. The study protocol was approved by the Ankara University Faculty of Medicine, Ethics Committee. The study was conducted in accordance with the principles of the Declaration of Helsinki.

\section{Statistical analysis}

Statistical analysis was conducted using R software. Frequencies, percentages, mean and median values were calculated for descriptive statistics. Wilcoxon's matched-pair signed rank test was used to evaluate within group changes in the FIM motor score. The level of statistical significance was 0.05 .

\section{RESULTS}

Patient's demographic and clinical characteristics are presented in Table 1 . The median time since injury was four months (IQR: 1-15). The median length of stay in the rehabilitation clinic was 76 days (IQR: 38-102). Eighty-three patients (70\%) were tetraplegic and 35 patients (30\%) were paraplegic.

Eighty-eight patients had traumatic and 30 patients had non-traumatic spinal cord injury. The most common causes of injury in the traumatic group were 
Table 1. Demographic and clinical characteristics of patients $(n=118)$

\begin{tabular}{|c|c|c|c|c|c|}
\hline & $\mathrm{n}$ & $\%$ & Mean \pm SD & Median & IQR \\
\hline Age (years) & & & $41 \pm 16$ & & \\
\hline Traumatic & & & $37 \pm 15$ & & \\
\hline Non-traumatic & & & $50 \pm 15$ & & \\
\hline Age at injury (mean, years) & & & $37 \pm 16$ & & \\
\hline Traumatic & & & $34 \pm 15$ & & \\
\hline Non-traumatic & & & $46 \pm 17$ & & \\
\hline \multicolumn{6}{|l|}{ Gender $(n=118)$} \\
\hline Female & 44 & 37 & & & \\
\hline Male & 74 & 63 & & & \\
\hline \multicolumn{6}{|l|}{ Traumatic patients $(\mathrm{n}=88)$} \\
\hline Female & 34 & 29 & & & \\
\hline Male & 54 & 46 & & & \\
\hline \multicolumn{6}{|l|}{ Non-traumatic patients $(\mathrm{n}=30)$} \\
\hline Female & 10 & 8 & & & \\
\hline Male & 20 & 17 & & & \\
\hline \multicolumn{6}{|l|}{ Marital status } \\
\hline Married & 75 & 64 & & & \\
\hline Single & 43 & 36 & & & \\
\hline Length of stay in rehabilitation (day) & & & & 76 & $46-104$ \\
\hline Time since injury/diagnosis (month) & & & & 4 & $1-15$ \\
\hline Traumatic & & & & 5 & $1-17$ \\
\hline Non-traumatic & & & & 4 & $2-14$ \\
\hline Paraplegic & 35 & 30 & & & \\
\hline Tetraplegic & 83 & 70 & & & \\
\hline Complete & 53 & 45 & & & \\
\hline Incomplete & 65 & 55 & & & \\
\hline \multicolumn{6}{|l|}{ Traumatic etiology } \\
\hline Traffic accidents & 38 & 32.2 & & & \\
\hline Diving & 1 & 0.8 & & & \\
\hline Falls & 36 & 30.5 & & & \\
\hline Gun wounds & 13 & 11 & & & \\
\hline \multicolumn{6}{|l|}{ Non-traumatic etiology } \\
\hline Infection & 2 & 1.7 & & & \\
\hline Vascular & 7 & 5.9 & & & \\
\hline Neoplasia & 5 & 4.2 & & & \\
\hline Degenerative & 10 & 8.4 & & & \\
\hline Other & 6 & 5.1 & & & \\
\hline
\end{tabular}

SD: Standard deviation; IQR: Interquartile range.

traffic accidents (32.2\%), falls (30.5\%) and gun wounds (11\%). Cause of injury in non-traumatic SCI patients consisted of degenerative disorders (spinal stenosis, spondylosis etc.) (8.4\%), vascular disorders (5.9\%), neoplasia (4.2\%) and infections (1.7\%).

The AIS scores were recorded at the time of admission and discharge. Among traumatic SCI patients, $47(53.5 \%)$ had a complete spinal cord lesion and the predominant grade was determined as AIS A (53.4\%), followed by AIS D (17\%) and AIS C (14.7\%).

Varying degrees of neurologic recovery was observed in patients with non-traumatic and traumatic SCI including those with a complete injury (Table 2). Four out of 47 patients (8\%) who were AIS $A$ at admission improved to $B$ at discharge and two patients who were
AIS A improved to C. Also the FIM motor scores showed significant improvement at discharge compared to admission $(\mathrm{p}<0.0001)$ (Table 3$)$.

Forty-five patients (38\%) were using indwelling urinary catheter and $45(38 \%)$ were using clean intermittent catheterization (CIC) for urinary drainage at admission. At discharge, 37 of 45 patients (82\%) using indwelling urinary catheter switched to CIC, with an overall rate $80 \%$ of the latter.

The most common complications were urinary tract infection $(n=83,70 \%)$, pressure ulcer $(n=37,31 \%)$, and pain $(n=33, \% 28)$ in this patient data set. Other less common complications were heterotopic ossification $5 \%$, deep venous thrombosis $9 \%$, pulmonary embolism $3 \%$ and vesicoureteral reflux $3 \%$. 
Table 2. Changes in the American Spinal Injury Association impairment scale according to etiology and lesion level

\begin{tabular}{|c|c|c|c|c|c|c|c|c|c|c|c|}
\hline & \multicolumn{6}{|c|}{ Admission (n) } & \multicolumn{5}{|c|}{ Discharge (n) } \\
\hline & $\mathrm{n}$ & $\mathrm{A}$ & B & $\mathrm{C}$ & $\mathrm{D}$ & $\overline{\mathrm{E}}$ & $\mathrm{A}$ & $\mathrm{B}$ & $\mathrm{C}$ & $\mathrm{D}$ & $\mathrm{E}$ \\
\hline \multicolumn{12}{|c|}{ Non-traumatic SCI } \\
\hline Complete & 6 & 6 & 0 & 0 & 0 & 0 & 5 & 1 & 0 & 0 & 0 \\
\hline Incomplete & 24 & - & 6 & 4 & 13 & 1 & - & 6 & 1 & 16 & 1 \\
\hline \multicolumn{12}{|c|}{ Traumatic SCI } \\
\hline Complete & 47 & 47 & 0 & 0 & 0 & 0 & 41 & 4 & 2 & 0 & 0 \\
\hline Incomplete & 41 & - & 12 & 13 & 15 & 1 & - & 10 & 12 & 18 & 1 \\
\hline
\end{tabular}

\section{DISCUSSION}

In this descriptive study, we evaluated the records of SCI patients who were admitted for an inpatient rehabilitation program in a tertiary referral university hospital between 2005-2010 regarding their demographic features, etiological factors, complications, neurological and functional outcomes.

The incidence and prevalence rates of paraplegia have been reported to be markedly higher when compared to tetraplegia in the literature. ${ }^{[6,7]}$ Interestingly, the majority of the patients (70\%) were tetraplegic in the current study. This might be explained by the fact that our clinic is a tertiary referral center admitting patients with relatively higher level of injuries and various complications.

Traumatic SCI usually affects young adults ${ }^{[8]}$ with an age range between $28-41$ years. ${ }^{[9]}$ Generally, the mean age of non-traumatic SCI patients is higher than that of patients with traumatic lesions. ${ }^{[10,11]}$ Similarly, the mean age of patients with traumatic SCI was 34 and it is comparably lower than that of patients with nontraumatic lesions in the current study. The majority of patients with SCI were male which is in concordance with the literature. ${ }^{[9,12-16]}$ Individuals affected by SCI are usually single since young adults are affected more commonly. However, in this study population, $63 \%$ of patients were married which could be explained by the relatively younger age of marriage in Turkey. The most common causes of injury in traumatic SCI worldwide is motor vehicle crash (39\%) followed by fall (28\%), and violence $(15 \%)^{[9]}$ and the current study yielded similar rates.
The overall median length of stay changes between 37-98 days in Europe. ${ }^{[9]}$ The median length of stay (76 days) in the current study is comparable with that of European countries but considerably longer than that of the United States. ${ }^{[17,18]}$ In Turkey, Muslumanoglu et al. ${ }^{[19]}$ and Coşar et al. ${ }^{[14]}$ reported relatively longer lengths of stay (94 and 85.5 days respectively). Since the rehabilitation facilities and community-based rehabilitation programs are insufficient, length of hospital stay is generally longer than that of other countries which have established rehabilitation strategies and community based rehabilitation settings.

Upon admission, 47 of 88 traumatic spinal cord injury patients were complete according to the AIS. The majority of the impairment was AIS A, followed by $\mathrm{D}$ and $\mathrm{C}$. This is similar with the study of Chen et al. ${ }^{[20]}$ from the USA. Among these patients; 4 improved to $\mathrm{B}, 2$ to $\mathrm{C}$ at discharge. Two of the AIS B patients improved to $\mathrm{C}$ and 3 of the $\mathrm{C}$ patients improved to D. Kirshblum et al. ${ }^{[21]}$ investigated the degree of AIS conversion between 1 and 5 years after SCI in 987 subjects. They noted that $5.6 \%$ patients who were neurologically complete (AIS A) one year after SCI might convert to an incomplete injury by year five, with $3.5 \%$ converting to AIS B and \%1 to either AIS C or D. In our study population, only two patients (1.6\%) who had cervical injury improved to AIS C from AIS A. ${ }^{[21]}$ Studies generally showed increases in ASIA motor scores within the first year after the injury. In addition to the conversion in AIS grades, incomplete SCI patients show greater motor recovery than complete patients. ${ }^{[22]}$ Motor recovery is faster

Table 3. Changes in functional independence measure motor score in groups with different etiologies

\begin{tabular}{|c|c|c|c|c|c|c|c|}
\hline & \multicolumn{3}{|c|}{ FIM motor - admission } & \multicolumn{3}{|c|}{ FIM motor - discharge } & \multirow[b]{2}{*}{$p$} \\
\hline & Mean \pm SD & Median & Min-Max & Mean \pm SD & Median & Min-Max & \\
\hline Non-traumatic SCI $(n=30)$ & $41.67 \pm 17.24$ & 40 & $14-75$ & $57.9 \pm 16.66$ & 62 & $21-79$ & $<0.001^{\star}$ \\
\hline Traumatic SCI $(\mathrm{n}=86)$ & $32.09 \pm 18.36$ & 26 & $13-87$ & $47.8 \pm 20.25$ & 53.5 & $9-89$ & $<0.001^{\star}$ \\
\hline
\end{tabular}

FIM: Functional Independence Measure; SD: Standard deviation; SCI: Spinal Cord Injury; P: Within-group changes; ${ }^{*}$ Statistically significant change. 
within the first three months and is nearly complete by nine months, usually reaching a plateau at 12 to 18 months after SCI. Armstrong, ${ }^{[13]}$ found that patients who were admitted to the hospital in the first six months had larger functional recovery. In concordance with this study, patients who had AIS conversion in our study population were all in the acute period (1-6 months). On the other hand, patients at chronic stage without any change in AIS scores, still showed functional improvements reflected by FIM scores. These findings emphasize the importance of sustained inpatient rehabilitation for SCI patients.

Independent of the etiology, the most common complication during the patient's lifetime in SCI is urinary tract problems, ${ }^{[23-25]}$ followed by pressure ulcers and neuropathic pain. ${ }^{[14]}$ In our study population, the most common complications recorded were in similar order; urinary tract infection, pressure ulcers, pain and followed by orthostatic hypotension, joint contractures, upper extremity problems, deep venous thrombosis and heterotopic ossification. Many of the patients (31\%) were admitted with an existing pressure ulcer and the notably high prevalence of pressure ulcers in the current SCI patient sample was probably related to the tetraplegic patients outnumbering the paraplegic patients and delayed admission to the inpatient rehabilitation. It is widely accepted that pressure ulcers are more common in tetraplegic patients than in paraplegics. ${ }^{[23]}$ In the literature, it was demonstrated that high level of injury and bed rest due to frequent urinary tract infections and pressure ulcers were determinants of extended length of stay. ${ }^{[26]}$

A considerably large number of patients were still using an indwelling urinary catheter at admission. During rehabilitation, most of the patients using indwelling catheter (82\%) were switched to CIC for urinary drainage. Considering the most frequently encountered complication being as urinary tract infection, change of urinary drainage method might have a dramatic effect on reducing the complication rate.

The current study has limitations. The patients were heterogeneous with respect to the etiology as the sample also included patients with non-traumatic spinal cord injury. Disease specific outcome measures (SCIM, etc.) for SCI could have been used for functional assessment instead of FIM. The limited sample size did not allow multivariate analyses to demonstrate the influence of clinical factors on functional outcome. Lastly, the long-term functionality of the patients were not evaluated after discharge.
In conclusion, inpatient rehabilitation in a tertiary referral hospital appears to provide substantial functional and motor gains in patients with SCI. The relatively longer duration of inpatient rehabilitation program is probably due to the limited number of acute rehabilitation centers and insufficient community based rehabilitation programs in our country.

\section{Declaration of conflicting interests}

The authors declared no conflicts of interest with respect to the authorship and/or publication of this article.

\section{Funding}

The authors received no financial support for the research and/or authorship of this article.

\section{REFERENCES}

1. Wyndaele M, Wyndaele JJ. Incidence, prevalence and epidemiology of spinal cord injury: what learns a worldwide literature survey? Spinal Cord 2006;44:523-9.

2. Kirshblum SC, Memmo P, Kim N, Campagnolo D, Millis S. Comparison of the revised 2000 American Spinal Injury Association classification standards with the 1996 guidelines. Am J Phys Med Rehabil 2002;81:502-5.

3. Keith RA, Granger CV, Hamilton BB, Sherwin FS. The functional independence measure: a new tool for rehabilitation. Adv Clin Rehabil 1987;1:6-18.

4. Granger CV, Hamilton BB, Linacre JM, Heinemann AW, Wright BD. Performance profiles of the functional independence measure. Am J Phys Med Rehabil 1993;72:84-9.

5. Küçükdeveci AA, Yavuzer G, Elhan AH, Sonel B, Tennant A. Adaptation of the Functional Independence Measure for use in Turkey. Clin Rehabil 2001;15:311-9.

6. Kurtzke JF. Epidemiology of spinal cord injury. Exp Neurol 1975;48:163-236.

7. van Asbeck FW, Post MW, Pangalila RF. An epidemiological description of spinal cord injuries in The Netherlands in 1994. Spinal Cord 2000;38:420-4.

8. Surkin J, Gilbert BJ, Harkey HL, Sniezek J, Currier M. Spinal cord injury in Mississippi. Findings and evaluation, 1992-1994. Spine (Phila Pa 1976) 2000;25:716-21.

9. National Spinal Cord Injury Statistical Center1. Spinal cord injury facts and figures at a glance. J Spinal Cord Med 2013;36:1-2.

10. McKinley WO, Seel RT, Hardman JT. Nontraumatic spinal cord injury: incidence, epidemiology, and functional outcome. Arch Phys Med Rehabil 1999;80:619-23.

11. Citterio A, Franceschini M, Spizzichino L, Reggio A, Rossi B, Stampacchia G. Nontraumatic spinal cord injury: an Italian survey. Arch Phys Med Rehabil 2004;85:1483-7.

12. Khazaeipour Z, Norouzi-Javidan A, Kaveh M, Khanzadeh Mehrabani F, Kazazi E, Emami-Razavi SH. Psychosocial outcomes following spinal cord injury in Iran. J Spinal Cord Med 2014;37:338-45.

13. Armstrong JC, Nichols BE, Wilson JM, Cosico RA, Shanks L. Spinal cord injury in the emergency context: review of 
program outcomes of a spinal cord injury rehabilitation program in Sri Lanka. Confl Health 2014;8:4.

14. Cosar SN, Yemisci OU, Oztop P, Cetin N, Sarifakioglu B, Yalbuzdag SA, et al. Demographic characteristics after traumatic and non-traumatic spinal cord injury: a retrospective comparison study. Spinal Cord 2010;48:862-6.

15. Ng YS, Jung H, Tay SS, Bok CW, Chiong Y, Lim PA. Results from a prospective acute inpatient rehabilitation database: clinical characteristics and functional outcomes using the Functional Independence Measure. Ann Acad Med Singapore 2007;36:3-10.

16. McKinley W, Santos K, Meade M, Brooke K. Incidence and outcomes of spinal cord injury clinical syndromes. J Spinal Cord Med 2007;30:215-24.

17. Spinal cord injury facts and figures at a glance. J Spinal Cord Med 2013;36:715-6.

18. Horn SD, Smout RJ, DeJong G, Dijkers MP, Hsieh CH, Lammertse D, et al. Association of various comorbidity measures with spinal cord injury rehabilitation outcomes. Arch Phys Med Rehabil 2013;94:75-86.

19. Müslümanoğlu L, Aki S, Oztürk Y, Soy D, Filiz M, Karan A, et al. Motor, sensory and functional recovery in patients with spinal cord lesions. Spinal Cord 1997;35:386-9.

20. Chen Y, Tang Y, Vogel LC, Devivo MJ. Causes of spinal cord injury. Top Spinal Cord Inj Rehabil 2013;19:1-8.
21. Kirshblum S, Millis S, McKinley W, Tulsky D. Late neurologic recovery after traumatic spinal cord injury. Arch Phys Med Rehabil 2004;85:1811-7.

22. Fawcett JW, Curt A, Steeves JD, Coleman WP, Tuszynski $\mathrm{MH}$, Lammertse D, et al. Guidelines for the conduct of clinical trials for spinal cord injury as developed by the ICCP panel: spontaneous recovery after spinal cord injury and statistical power needed for therapeutic clinical trials. Spinal Cord 2007;45:190-205.

23. Singh R, Rohilla RK, Siwach R, Singh Dhankar S, Kumar Magu N, Singh Sangwan S. Health-related problems and effect of specific interventions in spinal cord injury. An outcome study in Northern India. Eur J Phys Rehabil Med 2010;46:47-53.

24. McKinley WO, Tewksbury MA, Godbout CJ. Comparison of medical complications following nontraumatic and traumatic spinal cord injury. J Spinal Cord Med 2002;25:88-93.

25. Krause JS, Reed KS, McArdle JJ. A structural analysis of health outcomes after spinal cord injury. J Spinal Cord Med 2010;33:22-32.

26. Post MW, Dallmeijer AJ, Angenot EL, van Asbeck FW, van der Woude LH. Duration and functional outcome of spinal cord injury rehabilitation in the Netherlands. J Rehabil Res Dev 2005;42:75-85. 